\title{
クローン論文掲載の基準を考える
}

\section{Standards for papers on cloning}

Nature Vol. 439 (243)/19 January 2006

黄教授のスキャンダルも覚めやらぬなか、各論文誌は査読工程の見直しに取り組んでいる。専門家による 検討を受け、クローン関係の論文に対するNature の考え方をここに示す。

核移植で細胞や生物のクローンを得るのは、時間と費 用のかかるたいへんな作業である。発表された成果を 再現するには、何年という単位の時間がかかることも ある。だがその一方で、クローン化実験の正否は、作 業工程の中で集められた組織の DNA を調べることに よって、比較的容易に判断できる場合が多いという特 長をもつ。これは科学の世界では珍しいことだ。

査読の目的は結果の信頼性を評価することだが、虚 偽を見破るのは一般的にまず不可能である（ただし Natureでは現在、画像の改ざんに関して要領の見直し を行っている)。そして今後の査読も、基本的には信用 の上に立って行うしかないが、いったいどのようなデー タをチェックすれば、クローンであることが十分に証明 されるのだろうか。黄教授のスキャンダル以前は、あ る動物が核移植でクローン化されたものかぞうかを判 断するには、そのクローンと核ドナーに関する核 DNA フィンガープリントの同一性検査をもって、最終的に結 論されていた。他方、クローンのミトコンドリア DNA は核ドナーと一致しないはずなので、これを調べること で試料の誤操作や不正行為は明確に排除される。

今回の事件全体をふまえ、クローンに関するNature 投稿論文の著者には今後、核に加えてミトコンドリア DNA のフィンガープリントも示すよう求めることを考 えている。しかし、場合によっては、そうしたデータ の解釈には混乱要因がありうることに留意する必要が ある。たとえば、核ドナーのミトコンドリアの貢献度 は、種により、あるいはそれが種間雑種かどうかにより、 さらには用いた核移植技術により、さまざまだと考え
られる。また、新たな胚性幹細胞株を作製したことを 発表する論文の場合、試料の誤操作（意図的であるに せよ、偶発的であるにせよ）やほかの細胞株による污 染をはじくため、その株の核 DNA フィンガープリント を示して既存の株と比較することが必要となる。

論文投稿時には、ぞれだけのデー夕を提示すべきだろ うか？ クローンに関する論文の著者は、クローン化の手 順を論理的に示すため、またその効率性を示すため、そ のつぞ十分なデー夕が求められる。これに加えて Nature では、査読者や編集者による確認のために、必要に応じ て生デー夕の提供を求める場合がある。これにより、論 文に記載されたデー夕は生デー夕を正確に解釈したもの であるかどうかが確認でき、査読の過程で疑問が生じた 場合、別段階での追加検証作業を行うことができる。

\section{第三者試験}

黄教授を取り巻いた異例の状況を考慮して、Natureで は第三者の科学者に委託してイヌのスナッピー（B.C. Lee et al. Nature 436, 641；2005）が実際にクローンな のかぞうかを検証した。スナッピーと核ドナーの血液試 料から得たDNA フィンガープリントを分析したところ、 結果は肯定的なものだった。現在、その結果は発表に 向けて査読を受けている。しかし、2～3 人の科学者か ら、クローンの論文を掲載するときには常にこのような 第三者試験を条件にするべきだという指摘があった。

Natureではこの指摘を慎重に検討してきたが、クロー ンの分野に対してそうした基準を揭載の条件として課 すのは過剩反応であり、種々の複雑な問題が避けられ 
なくなるという結論に達した。たとえば、誰が試験の費 用を負担するのか、試料の誤操作をどう回避するのか、 検証試験は負担の大きい特別作業となるが、担当する 科学者はどう報われるのかなどの問題である。さらに、 不正行為が起こりうるのはクローンの分野だけとは限 らず、ならば揭載論文すべてに第三者の検証が必要だ ということにもなるが、それは現行システムでは無理な 話である。過剩すぎる検証で本来掲載されるべき論文 が揭載されないことにもなれば、めったにない不正行 為を検出することのメリットは意味を失ってしまう。

「傑出した主張には特別の証拠が必要なのだと いう原則にのっとり、場合によっては、Nature ではそれを要求する。」

しかし、Natureでは科学に対して最大限の寄与をす べく、画期的なクローン研究に取り組む研究者に対し、 研究者自らが第三者による検証を求めるとともに、最 初の論文投稿時にその結果を添付することを推奨する。 そして、傑出した主張には特別の証拠が必要なのだと いう原則にのっとり、場合によっては、Natureではそ うした第三者検証を要求していく。

Nature をはじめとする多くの科学誌では、関連する 試薬類を科学界に提供できるようにすることを論文掲 載の条件として著者に求め、細胞株および変異体を確 実な貯蔵場所に保管するよう勧めている。しかし現在 では、各誌がさらに踏み込んだ対応を取り、重要な試 料は米国基準培養株コレクション（ATCC）のような貯 蔵場所に保管し、論文の発表後にほかの研究者が低コ
ストで迅速に利用できるよう要求すべきだとの指摘が なされている。Natureでは、そのようなことが要求で きるかぞうか検討しており、要求すべきかぞうか、する とすればどのような形が最適か、広く意見を求めたい。 画期的なものとなるかもしれないクローン研究に取り 組む科学者は、貯蔵場所がぞこであれ、重要な試料は 後日の検証のために間違いなく適切に保管するようにし てほしい。この作業の一環として、核ドナー、卵母細胞 ドナー、抢よび作製された動物または幹細胞株の細胞 は、当該研究に関与しない第三者の科学者によって入 手、保管される必要がある（または実際に保管されて いるかを監視する必要がある)。この予防措置はヒトド ナーの場合、特に重要となる。後日、検証用として被験 者から組織を入手し直すことができない場合も考えら れるからだ。資金拠出機関による資金の提供は、後日の 試料検証を保証する措置を前提に行われるべきである。 また、研究機関においても、内部の調査委員会が研究 を承認する段階で確実な試料保管を要求するべきだ。

黄教授の事件を受け、科学は本来、多分に自己修正 的なプロセスであり、科学者、編集者、查読者、ジャー ナリスト、資金拠出機関、および研究機関がそれぞれ 重要な修正機能を担っているのだということが改めて 思い起こされた。今回の論文秝つ造は異常ともいえる 事態だったが、紋切り型の反応や魔女狩りには用心し たい。それでは何も変わらない。Natureでは、再発 防止のために工程と基準を精査していくことを約束 し、この取り組みに対する読者からの意見を歓迎する (e-mail の送信先は、authors@nature.com)。 